\title{
Low-intensity laser therapy and led (light emitting diode) therapy in mechanical resistance of Rattus norvegicus chest inscision with implant of steel wire for sternal suture
}

Rauirys de Alencar de Oliveira*, André Fernandes Matos, Nara Regina Batista Barros, Gilderlene Alves Fernandes, Andréa Conceição Gomes Lima, Renata Amadei Nicolau

\begin{abstract}
Introduction: Low-intensity laser (LILT) and LED therapy are indicated in repairing surgical incisions, which occur in cardiac surgery. One major concern in this case is the presence of metallic wire used for sternal sutures, its temperature may rise while using a laser or LED. This study aimed to analyze the tensiometric properties of the skin tissue with longitudinal incision and metallic wire implant used for sternal suture irradiated with LILT and LED. Methods: Twenty-five subjects (Rattus norvegicus) were submitted to thoracic incision with implantation of metallic wire, and subsequently divided into five groups: GI (control group);

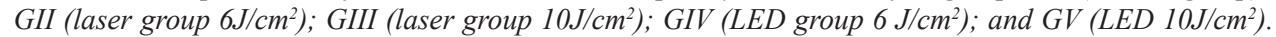
Photobiomodulation was performed on a daily basis for eight consecutive days and the local temperature was measured before and after phototherapy. After euthanasia the tissues were subjected to tensiometric and histological analysis. Results: All irradiated groups showed increase in break strength $(p=0.009)$, and decrease in tissue deformation strength compared with the control group $(p=0.03)$. Conclusion: Both LILT and LED can promote wound healing at the tested doses with increased tissue resistance, although its elasticity is reduced. The imprecision of the assessing instruments precluded an accurate measurement of a possible local tissue heating post irradiation and future studies are need to elucidate this effect.
\end{abstract}

Keywords Low-intensity laser therapy, LED, Interaction laser biological tissue. 


\section{Introduction}

The low-intensity laser therapy (LILT) has been applied in tissue repairing and acceleration of the healing process, being a study object in numerous medical areas. The LED (light emitting diode) arises with the development of technological systems of light production and emission, being a hopeful alternative for tissue repair therapy (Meyer et al., 2010; Sousa et al., 2010; Trelles and Allones, 2006). Despite this fact, the number of researches about this technique comparing LILT to LED therapy is still insufficient.

The laser is characterized by the monochromaticity, collimation and consistency of the emission of its light beam. Its application has been widespread in medicine and physical therapy due to its therapeutic effects as analgesic, anti-inflammatory and tissue repairer (Brugnera, 2004). LILT stimulates release of growth factors by macrophages, increases keratinocytes proliferation and increases the number of mast cells (its granulation and even angiogenesis). The photons emitted by laser are converted into chemical and kinetic energy within the cell, which modifies the membrane permeability and increases the nitric oxide formation. The increase in oxidative metabolism may result in an increase of ATP synthesis (glycolysis and oxidative phosphorylation), which leads to cell function adjustment (Leal Junior et al., 2009). Calcium is released from mitochondria due to proton gradient increase within the cytoplasm, which generates regulation of cellular metabolism, repair, cell migration and proliferation, RNA, DNA and protein synthesis. There is an increase in immune response, with activation of $\mathrm{T}$ lymphocytes and macrophages (Giuliani et al., 2004), endorphin levels also increase and a parallel decrease of bradykinin resulting in pain relief (Lorenzini et al., 2010).

The high manufacture cost of laser emitting devices, besides the large number of parameters to be selected (such as fluency, power, treatment time and irradiance), encouraged researchers to develop alternative sources of phototherapy, such as light emitting diode (LED). Some studies show evidence that irradiation with non-coherent light proved to be more profitable and can be as efficient as laser radiation (Casalechi et al., 2009; Corazza et al., 2007; Dall-Agnol et al., 2009).

LED devices, according to Andrade et al. (2001), are systems that produce monochromatic and high cleanliness light when energized. Those systems work with semiconductors that present the characteristic of conducting electric current in one direction only. Although this type of light is present in our daily lives in many electronic components, its use as photobiomodulator is recent (Guaratini et al., 2007).

Other interesting features reported on LED show that its light emission is more selective when compared to regular bulbs, the device has more durability and need less electrical power for its operation. On the other hand, the device temperature increase during its operation is meaningless, thus not causing further damage to the unit even if it is used for prolonged periods (Kurachi et al., 2001). Those aspects associated to low cost and convenience, are leading LED devices to conquer the market, also they have been tested and studied increasingly in terms of their therapeutic properties. Minatel et al. (2009) reported in their study that LED therapy shows a wide variety of effects, as well as pain relief, tissue healing and anti-viral properties.

Among the biophysical effects of photobiomodulators, as low-intensity laser and LED therapy, is the heating caused by electromagnetic waves radiation in the infrared or red spectrum (Casalechi et al., 2009). In this manner, a better understanding of the healing process mediated with photobiomodulators and also skin heating processes using low-level laser and LED therapy are important in terms of providing more safety to the technique, obtaining the best results using recommended therapeutic doses without excessive tissue heating.

LED therapy and LILT have been used to irradiate surgical incisions in order to accelerate the postoperative recovery (Trelles and Allones, 2006). However, some specific surgeries require equally specific care. Cardiovascular surgery with sternotomy, for example, requires sternum suture with stainless steel wire, a heat sensitive material which may heat up when irradiated indirectly by LILT or LED therapy. This study aimed to analyze the tensiometric properties of the skin tissue with longitudinal incision and with a subcutaneous implant of a metallic wire used for sternal suture irradiated with LILT and LED.

\section{Methods}

This research was submitted to approval of the Ethics Committee from the Integral Diferencial University (FACID), being authorized by the protocol number $022 / 11$. The procedures followed the recommendations of the Institute of Laboratory Animals Resources of the National Academy of Science Guide for the care and use of laboratory animals, Washington DC, and the Brazilian College of Animal Experimentation (COBEA) guideline.

Twenty-five male albinos Wistar rats (Rattus norvegicus) weighing $246.3 \pm 50.7 \mathrm{~g}$ were 
studied. They were randomly organized in appropriate cages and subjected to a light/dark cycle of 12 hours each, starting the light phase at 7 a.m. with an environment temperature of $23{ }^{\circ} \mathrm{C} \pm 1$, with food and water ad libitum, at the bioterium from the University of Health, Human and Technological Sciences of Piauí - NOVAFAPI, in Teresina - PI.

The animals were anesthetized with a mixture of $10 \%$ ketamine and $2 \%$ xylazine, in the proportions $1: 2$, at doses of $0.10-0.15 \mathrm{~mL}$ per $100 \mathrm{~g}$ of body weight, intramuscularly. The upper sternum was shaved for hair removing. Then an incision, $4 \mathrm{~cm}$ length, was performed using a scalpel blade for a monofilament of Aciflex ${ }^{\mathrm{TM}}$ No. 3, which is a stainless austenitic steel $360 \mathrm{~L}$ wire, (18\% Cr 10\% Ni 2\% Mo), nonabsorbable, $480 \mathrm{~J} /\left(\mathrm{kg}^{\circ} \mathrm{C}\right)$ specific heat and $14 \mathrm{~W} /\left(\mathrm{m}^{\circ} \mathrm{C}\right)$ thermal conductivity at $20^{\circ} \mathrm{C}$. The monofilament was cut, $4 \mathrm{~cm}$ length, and longitudinally positioned on the sternum and then fixed with a monofilament of nylon synthetic nonabsorbable wire No. 3 at $0.5 \mathrm{~cm}$ from each edge of the steel wire, as observed in Figure 1. Finally, the skin wound was sutured with nylon wire (Figure 1). Upon surgery conclusion a single dose of Pencivet, an antibiotic $1 \mathrm{ml} / \mathrm{kg}$ was administered to all groups intramuscularly.

After surgery, the subjects were divided into five groups of five animals each, being four experimental groups and one control group, distributed as follows: GI (control group); GII (laser group $6 \mathrm{~J} / \mathrm{cm}^{2}$ ); GIII (laser group $10 \mathrm{~J} / \mathrm{cm}^{2}$ ); GIV (LED group $6 \mathrm{~J} / \mathrm{cm}^{2}$ ) and; GV $\left(\right.$ LED $\left.10 \mathrm{~J} / \mathrm{cm}^{2}\right)$. The first irradiation was performed two hours after surgery and then daily until the eighth postoperative day, in a total of eight sessions.

The equipment used for the LILT was a Laser Hand model (InGaAlP), MMOptics ${ }^{\mathrm{TM}}$. The device was adequately calibrated by the supplier. The LED therapy equipment was Starlaser model, Microdont ${ }^{\mathrm{TM}}$ (Table 1). The equipment was calibrated at the Laboratory of Tissue Biomodulation at the University of the Paraíba

Table 1. Parameters of the instruments used for phototherapy.

\begin{tabular}{lccccc}
\hline \multirow{2}{*}{ Parameters } & \multicolumn{2}{c}{ Laser $(660 \mathbf{~ n m})$} & & \multicolumn{2}{c}{ LED $(\mathbf{6 4 0} \pm \mathbf{2 0} \mathbf{~ n m})$} \\
\cline { 2 - 3 } \cline { 5 - 6 } & GII & GIII & & GIV & GV \\
\hline ED $\left(\mathrm{J} / \mathrm{cm}^{2}\right)$ & 6 & 10 & & 6 & 10 \\
E $(\mathrm{J})$ & 2.4 & 4 & & 10.1 & 18 \\
P $(\mathrm{W})$ & 0.04 & 0.04 & & 0.07 & 0.07 \\
$\varnothing(\mathrm{cm})$ & 0.5 & 0.5 & & 1.5 & 1.5 \\
$\mathrm{~A}\left(\mathrm{~cm}^{2}\right)$ & 0.4 & 0.4 & & 1.77 & 1.77 \\
$\mathrm{~T}(\mathrm{~s})$ & 60 & 100 & & 152 & 253 \\
$\mathrm{PD}\left(\mathrm{W} / \mathrm{cm}^{2}\right)$ & 0.1 & 0.1 & & 0.03 & 0.03 \\
\hline
\end{tabular}

GII - group II; GIII - group III; GIV - group IV; GV - group V; ED - energy density; E - energy; $\mathrm{P}$ - power; $\varnothing$ - diameter; A - beam area; $\mathrm{t}$ - time of irradiation; $\mathrm{PD}$ - potency density.
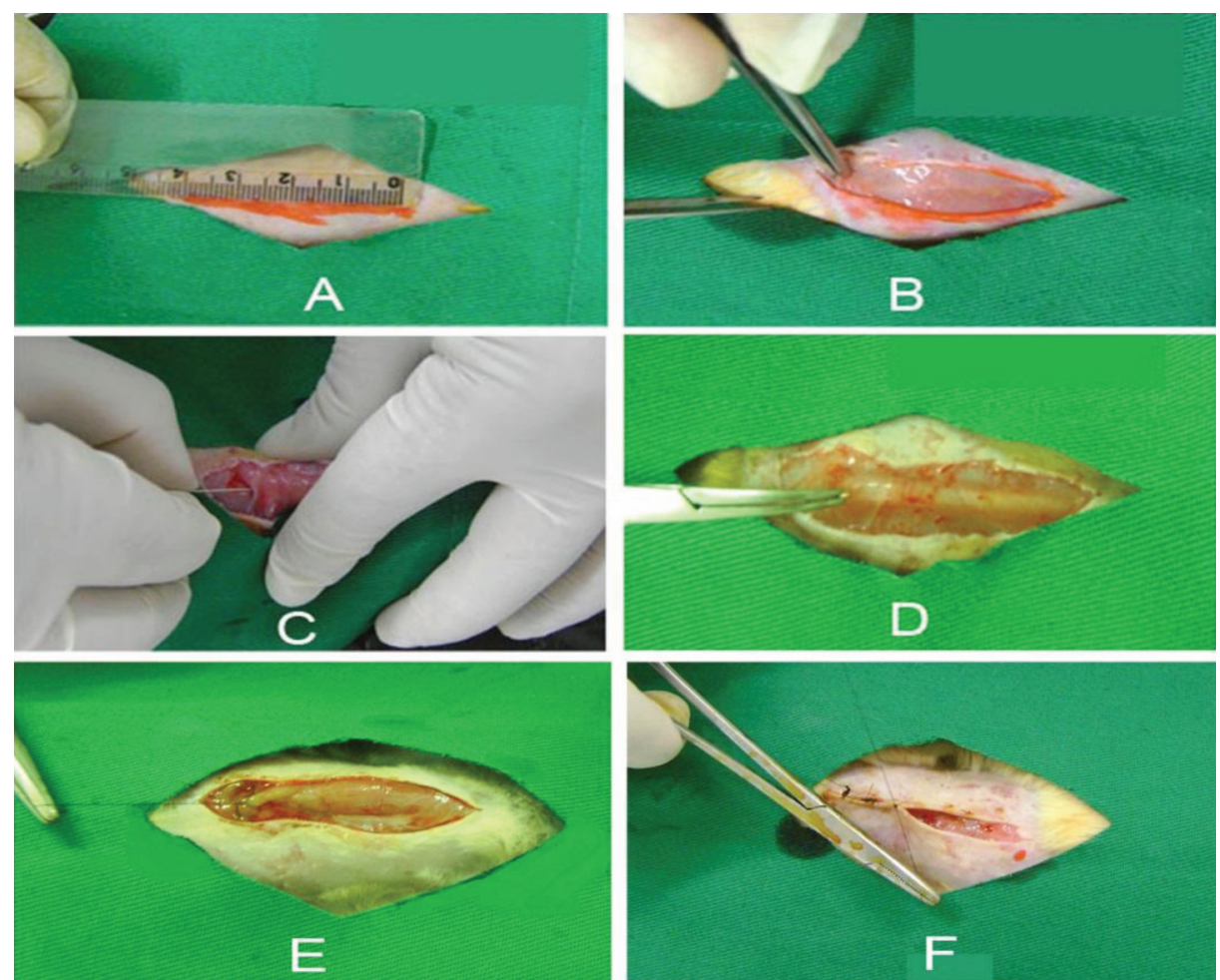

Figure 1. Surgical procedure: A) Incision area measurements; B) Surgical incision; C) Introduction of the wire; D) Positioning along the sternum; E) Fixing the wire into the surrounding tissue with nylon; F) Suture of the skin edges with nylon. 
Valley (UNIVAP). The edge of the laser or LED emitter was wrapped with a translucent plastic film and then positioned $0.5 \mathrm{~cm}$ far from the irradiation area of the subject's chest. The irradiation was performed in two incision spots, $2 \mathrm{~cm}$ away from each other.

The studied variables were the local heating, the tissue maximal break strength and maximal deformation strength, and the presence of histological signs of tissue damage due to heating, such as blistering or necrosis.

The body temperature was assessed by a precision infrared thermometer, Testo $^{\mathrm{TM}}, 830 \mathrm{~T} 1$ model, ranging from $-30{ }^{\circ} \mathrm{C}$ to $+400{ }^{\circ} \mathrm{C}$ and $0.5^{\circ} \mathrm{C}$ of resolution and $1.5 \%$ of m.v. The skin temperature was measured exactly at the LILT and LED irradiation spot, before and immediately after irradiation, maintaining a distance of approximately $2 \mathrm{~cm}$ far from the thermometer sensor and the animal skin, as represented in Figure 2. This procedure was repeated daily until the 8th day after surgery. In the case of the control group, the animals had their temperature measured every day until the 8th day after surgery at the corresponding skin spot of the other groups.

On the eighth day after surgery the animals were euthanatized using pentobarbital at a dose of $100 \mathrm{mg} / \mathrm{kg}$ via intraperitoneal route. A tissue sample, $3 \mathrm{~cm}$ long and $4 \mathrm{~cm}$ wide, was withdrawn of each animal by a scalpel blade, transversally to surgery incision scar, and submerged into a recipient with Ringer Lactate solution for transportation to the Mechanical Testing Laboratory of the National Service of Industrial Learning in Teresina (PI) for tensiometric tests performed with an equipment DL20000 $\mathrm{Emic}^{\mathrm{TM}}$. The travel time between the bioterium and the Mechanical Testing Laboratory consisted of less than 30 minutes, minimizing the possible mechanical changes of the tissue caused by the analysis delay. The grip pressure was manually adjusted and the data were electronically acquired by the $\mathrm{Tesc}^{\mathrm{TM}}$ software, version 1.01. The pressure claws were positioned $1.5 \mathrm{~cm}$ far from each other, fixing the tissue with the scar at an equal distance to the edges of the claws (Figure 3). The maximal break strength and maximal deformation strength of the tissue were measured at a speed of $50 \mathrm{~mm} / \mathrm{min}$.

A small piece of the same tissue was removed for microscopic analysis of the subcutaneous area surrounding the metallic implant. As this tissue was in close contact with the metallic wire, it would be more likely that it would suffer injury by the apparent heating of that material. The tissue was preserved into formaldehyde $10 \%$, then kept with water softener for 2 days and, finally, sliced with a microtome in sections of $4 \mu \mathrm{m}$ thickness and colored with eosin hematoxylin. The histological slides were analyzed by an optical microscope.

The maximal break strength and maximal deformation strength were statistically analyzed by Kruskal-Wallis test and Turkey HSD post-hoc test. The tissue heating was analyzed using the Wilcoxon sum runk test. Statistic analyses were performed using the software Statistica 7.0 StatSoft ${ }^{\mathrm{TM}}$. Confidence interval of $95 \%$ and $p \leq 0.05$ were considered as statistically significant.

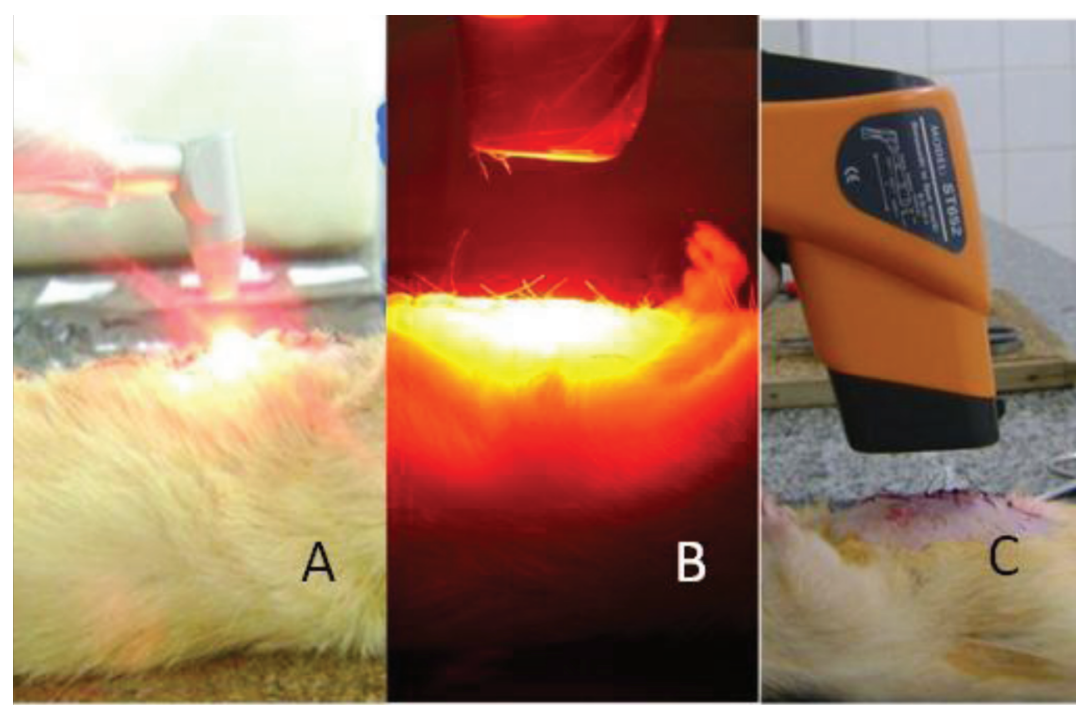

Figure 2. Incision temperature measurement: A) Laser irradiation; B) LED irradiations; C) Temperature measurement. 

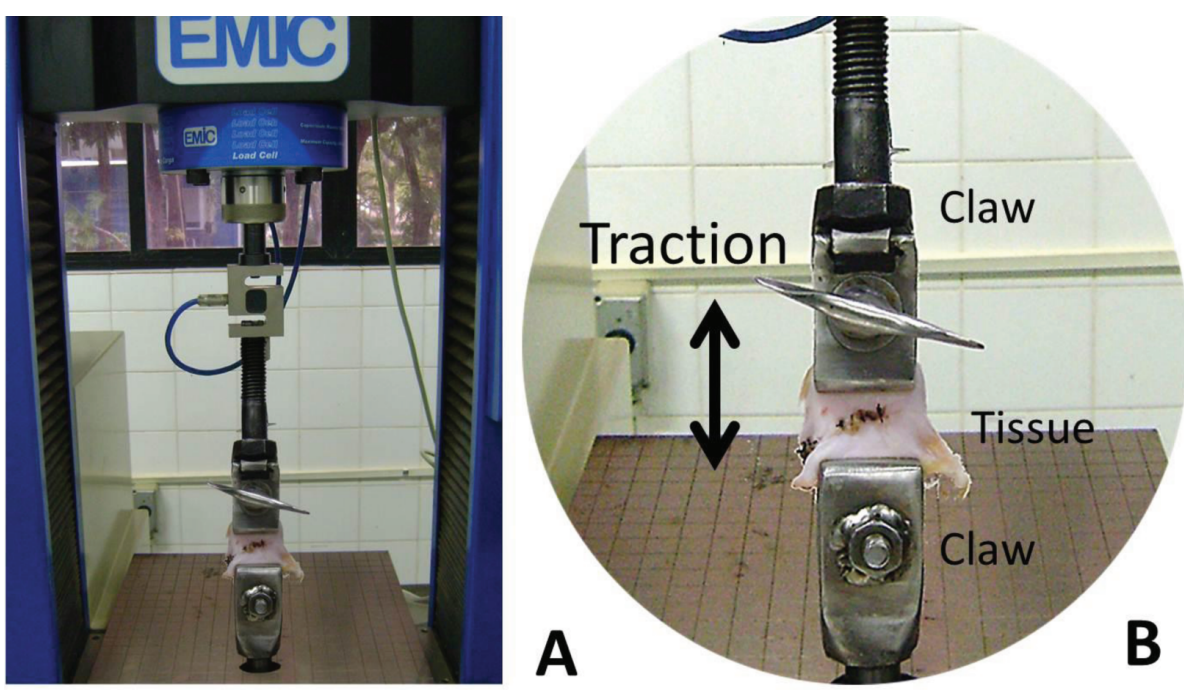

Figure 3. Tensiometric analysis: A) Equipment for tensiometric analysis at the Mechanical Testing Laboratory of the National Industrial Learning Service in Teresina (PI), model DL2000 (Emic ${ }^{\circledR}$ ); B) Positioning and stretching the tissue.

\section{Results}

\section{Macroscopic aspects and microscopic analysis}

In the macroscopic assess of the lesions, signs of infection were detected in tissue adjacent to the steel wire in two rats, one of GII and other of GIV. Suture dehiscence of the skin was also detected in other animal (GV). All of them were excluded from the study. The microscopic analysis showed no evidences of tissue overheating, such as swelling, blistering or tissue necrosis. Furthermore, all groups presented vascular increase (Table 2).

\section{Local tissue temperature}

All groups showed increase in temperature after irradiation, as seen in Table 2. Moreover, due to the minor temperature values recorded in the tissues and the accuracy limits of the instrument, this possible tissue heating cannot be statistically demonstrated or compared. Furthermore, according to results the average temperature increase in LED $6 \mathrm{~J} / \mathrm{cm}^{2}$ group was $1.07 \pm 0.26{ }^{\circ} \mathrm{C}$, in LED $10 \mathrm{~J} / \mathrm{cm}^{2}$ group was 1.58 $\pm 0.22{ }^{\circ} \mathrm{C}$, in Laser $6 \mathrm{~J} / \mathrm{cm}^{2}$ group $0.37 \pm 0.11^{\circ} \mathrm{C}$ and Laser $10 \mathrm{~J} / \mathrm{cm}^{2} 0.59 \pm 0.25^{\circ} \mathrm{C}$, as indicated in Figure 4 .

\section{Tensiometric analysis}

The maximal break strength (MBS) is the highest tension the tissue supports before rupturing, measured in gram $\times$ force $(\mathrm{gf})$. The results showed that MBS was higher in LED $6 \mathrm{~J} / \mathrm{cm}^{2}$ group $(\mathrm{p}=0.04)$, LED $10 \mathrm{~J} / \mathrm{cm}^{2}(\mathrm{p}=0.02)$ and laser $6 \mathrm{~J} / \mathrm{cm}^{2}(\mathrm{p}=0.03)$ when compared to the control group. Only $10 \mathrm{~J} / \mathrm{cm}^{2}$ laser group did not improve the MBS, according to Kruskal-Wallis test (Figure 5).

The maximal deformation strength (MDS) is the highest deformation the tissue supports before rupturing. The LED $6 \mathrm{~J} / \mathrm{cm}^{2}$ group showed less tissue deformation compared to LED $10 \mathrm{~J} / \mathrm{cm}^{2}$ group $(\mathrm{p}=0.03)$ and control group $(\mathrm{p}=0.02)$, as seen in Figure 6 . The other groups showed no significant difference compared to the control group.

\section{Discussion}

\section{Microscopic analysis}

Sternal dehiscence and infection are serious surgical complications by high morbidity, mortality and also difficult to control, leading researchers to pursuit new diagnostic and therapeutic methods. According to the classification proposed by the Center for Disease Control and Prevention (CDC-USA), infection in the incision of sternotomy should be considered superficial if it affects only the skin and subcutaneous tissue, and deep when it extends to the sternum. The infection can involve other structures surrounding the sternum causing sternal osteomyelitis or mediastinitis. This study analyzed the incidence of superficial wound infection, which according to Brocki et al. (2010) affects between $1.6 \%$ and $6.4 \%$ individuals after surgery. In this study, $7.14 \%$ developed superficial infection.

The incidence of suture dehiscence was 3.57\%. There is not a specific etiology for this incidence, but 
Table 2. Microscopical analysis.

\begin{tabular}{lcccc}
\hline Group & Swelling & Blistering & Necrosis & Vascular increase \\
\hline LED $6 \mathrm{~J} / \mathrm{cm}^{2}$ & - & - & - & ++ \\
LED $10 \mathrm{~J} / \mathrm{cm}^{2}$ & - & - & - & ++ \\
Laser $6 \mathrm{~J} / \mathrm{cm}^{2}$ & - & - & - & + \\
Laser $10 \mathrm{~J} / \mathrm{cm}^{2}$ & - & - & - & ++ \\
\hline
\end{tabular}

Absent (-); discrete (+); moderate (++); severe (+++).

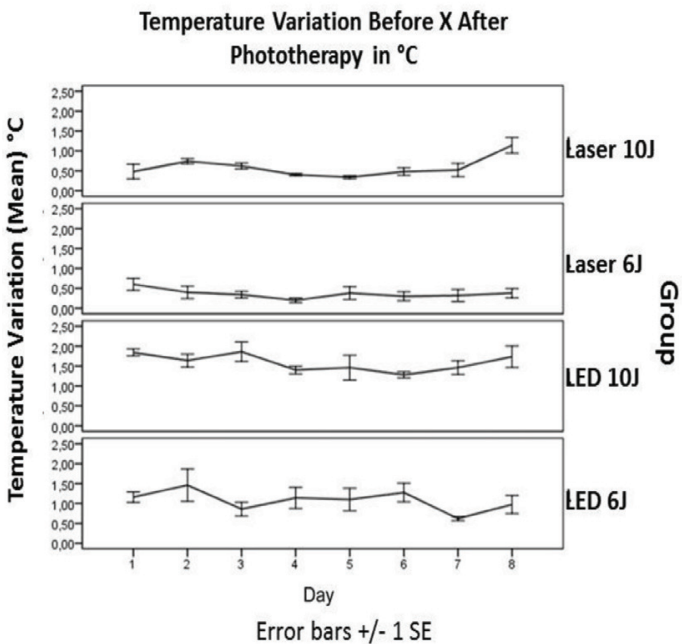

Figure 4. Temperature variation before $\mathrm{X}$ after phototherapy with LED and laser - Mean $\left({ }^{\circ} \mathrm{C}\right)$ and standard error.

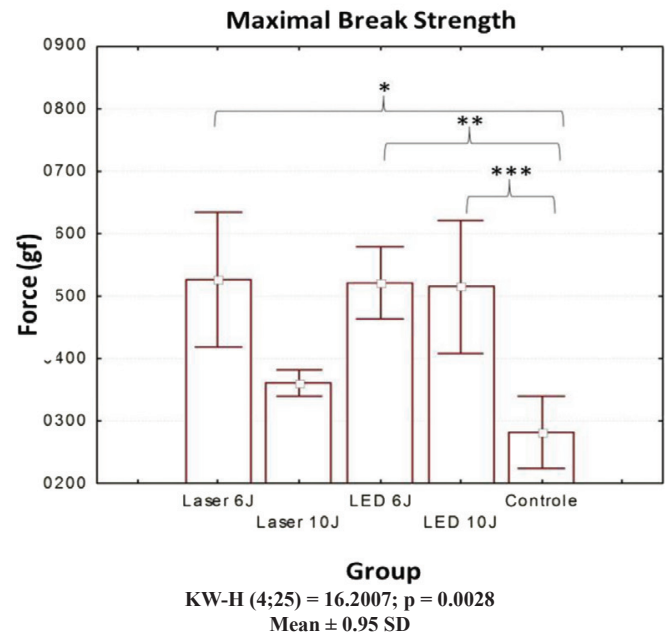

Figure 5. Median and standard error of the maximum force of rupture in terms of gram $\times$ force. Kruskal-Wallis Test $(\mathrm{KW}-\mathrm{H})$. Turkey HSD test showed significant differences between Laser $6 \mathrm{~J}$ x Control $(* \mathrm{p}=0.03)$, LED $6 \mathrm{~J} \times$ Control $(* * \mathrm{p}=0.04)$ and LED $10 \mathrm{~J}$ $\mathrm{x}$ Control $(* * * \mathrm{p}=0.02)$.

it is assumed that these results are due to the animal's own contact with the surgical wound.

There was no evidence of blisters and necrosis surrounding the tissue. This circumstance can be justified by the fact that the photobiomodulators intensities used in this research could not achieve

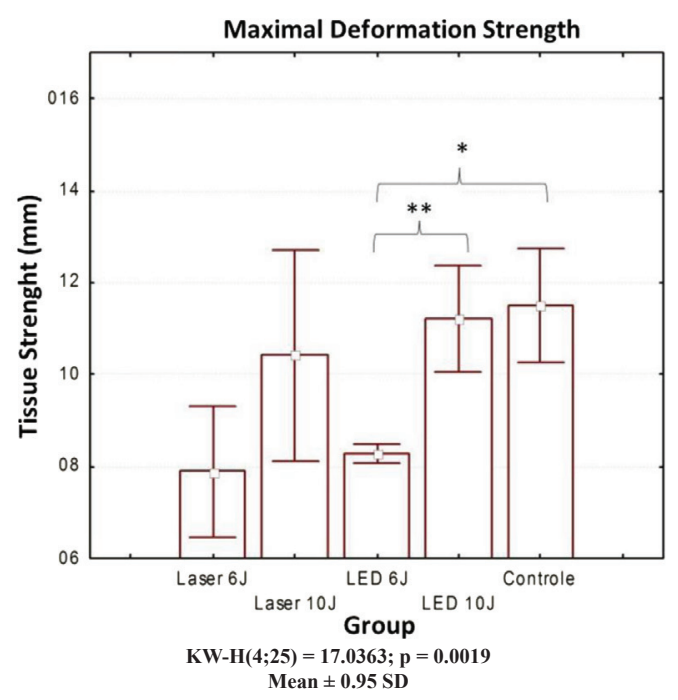

Figure 6. Graph of the mean and standard error of the tissue deformations in each group in millimeters. Kruskal-Wallis test (KW-H). Turkey HSD test showed significant differences between LED $6 \mathrm{~J} \times$ LED $10 \mathrm{~J}(* \mathrm{p}=0.03)$ and LED $6 \mathrm{~J} \times \mathrm{Control}(* * \mathrm{p}=0.02)$

a temperature level required to cause cell injury by heating. The biological effects of laser therapy are not thermal. Only the high-power lasers, operating with powers up to $1 \mathrm{~W}$, whose effects are related to the high and rapid local heating of the tissue, can cause cellular damage due heating (Ignatieva et al., 2011).

\section{Tissue heating}

The groups irradiated with coherent light (laser) showed no significant temperature change comparing the measures taken before and after irradiation. This result is consistent with other reported studies. According to Capon and Mordon (2003), the use of doses smaller than $35 \mathrm{~J} / \mathrm{cm}^{2}$ are considered too low to make any detectable warming in irradiated tissues. Ignatieva et al. (2011) advised that the change in temperature due to LILT results in a maximum $1^{\circ} \mathrm{C}$, which is sufficient to produce the photothermal effect. However the results showed an average increase of $0.59 \pm 0.25^{\circ} \mathrm{C}$ with laser $10 \mathrm{~J} / \mathrm{cm}^{2}$ and $1.58 \pm 0.22{ }^{\circ} \mathrm{C}$ with LED $10 \mathrm{~J} / \mathrm{cm}^{2}$.

Circeli et al. (2009) carried out a research on fibroblasts cells heating when irradiated with therapeutic LED and found that there was no significant 
increase in temperature, comparing the increase in time due to the cumulative effect of radiation. The temperature difference was $7{ }^{\circ} \mathrm{C}$ between groups irradiated with dose of $10.5 \mathrm{~J} / \mathrm{cm}^{2}$ and $37.5 \mathrm{~J} / \mathrm{cm}^{2}$, using two distinct intensities: $12.5 \mathrm{~mW} / \mathrm{cm}^{2}$ and $25 \mathrm{~mW} / \mathrm{cm}^{2}$. Nevertheless, few studies have been conducted on the thermal effects of LED therapy. The present study showed that there are evidences proposing that LED increases local temperature to a higher level when compared to LILT. It is important to note that this possible heating is unable to cause tissue damage independently, even in the presence of metal wire. These results show evidences that the LED therapeutic technique is safe when used to irradiate sternotomy sutured with steel wire.

\section{Tensiometric analysis}

The healing process is responsible for the skin integrity maintenance, resulting in higher tensile strength. Among the cellular response involved in repair process, we can mention the complex interaction of inflammatory cells such as neutrophils, lymphocytes, monocytes and macrophages (Uribe et al., 2009).

The fibroblasts collagen synthesis, induced by light stimulation, is the key to explain the increase in maximal break strength in tissues irradiated with laser or LED, which decreased in the control group.

There are several mechanisms by which photobiomodulators can induce mitotic activity of fibroblasts. Among them, the most relevant to this study is that they stimulate the basic fibroblast growth factor (FGF-b) production, which is a multifunctional polypeptide secreted by the fibroblasts, being capable to induce not only proliferation but also fibroblast differentiation (Circeli et al., 2009). Fushimi et al. (2012), in an in vivo study with skin wounds, showed that green LEDs promote wound healing by inducing migratory and proliferative mediators, which suggests that not only red LEDs but also green LEDs can be a new powerful therapeutic strategy for wound healing. They also showed that LILT and LED can stimulate immune cells to secret cytokines and other growth regulatory factors.

In vitro studies, using macrophage cell lineage, indicated that when these cells are submitted to LILT they release soluble factors promoting fibroblast proliferation. The fibroblasts growth and its movement through the matrix are also influenced by laser irradiation (De Araujo et al., 2007). Studies have also implied that LILT increases fibroblast proliferation regardless of the wavelength applied. These studies also showed that there is an increase in fibroblast proliferation in tissues irradiated with lower energy densities $\left(4-6 \mathrm{~J} / \mathrm{cm}^{2}\right)$ compared to those irradiated with higher doses. However, the limits of energy density to achieve a better response of fibroblasts are still not very clear.

According to Fushimi et al. (2012), coherent and non-coherent light (laser and LED) at the same parameters of wavelength, intensity and dose, provide the same biological response, which is confirmed by Sousa et al. (2010). Therefore, coherence was not essential in obtaining the same effects of laser using LED. Whelan et al. (2001) enhances this understanding when stating that coherence is lost at the first few layers of biological tissue.

In terms of Maximal Deformation Strength (MDS), the present study showed that there was a decrease in the elasticity of irradiated tissues, especially those irradiated with lower energy densities, when compared to control group. The differences where more significant between LED $6 \mathrm{~J} / \mathrm{cm}^{2} \times$ LED $10 \mathrm{~J} / \mathrm{cm}^{2}$ groups $(\mathrm{p}=0.03)$ and LED $6 \mathrm{~J} / \mathrm{cm}^{2} \times$ Control group $(\mathrm{p}=0.02)$, as showed in Figure 6. This result can be explained by the fact that the scar has only about $80 \%$ of the resistance compared to normal skin, however, their ability to resist deformation is decreased due to the collagen deposition and the fibrils rearrangement (Baum and Arpey, 2005; De Araujo et al., 2007; Reis et al., 2008).

Some studies indicate that energy densities over $12 \mathrm{~J} / \mathrm{cm}^{2}$ cause inhibitory effects, delaying tissue repair (Houreld and Abrahamse, 2007). Circeli et al. (2009) conducted LED therapy with different energy densities levels irradiated in fibroblast culture. The doses used were $10.5,18,25.5,37.5 \mathrm{~J} / \mathrm{cm}^{2}$ in two different intensities $\left(12.5\right.$ and $\left.25 \mathrm{~mW} / \mathrm{cm}^{2}\right)$. The results suggested that LED caused a statistically significant reduction in cellular metabolism of the irradiated groups when compared to the control group. This fact could also explain the decreased tissue ability of stretching after being irradiated with higher intensities of laser or LED.

Hawkins and Abrahamse (2005) irradiated human skin fibroblasts with LILT, using doses of 0.5, 2.5, 5.10 and $16 \mathrm{~J} / \mathrm{cm}^{2}$ for two consecutive days. The results showed that doses of $5 \mathrm{~J} / \mathrm{cm}^{2}$ stimulated mitochondrial activity, cell proliferation and fibroblasts migration. However, higher doses decreased cell viability and proliferation with damage to the cell membrane and DNA.

The results reported in this study emphasized the need for a better understanding about the optimum dose of LILT or LED therapy to obtain improved results in terms of mechanical resistance to deformation of the biological tissue.

Based on the parameters found by tensiometric analysis, the present study can conclude that 
photobiomodulators irradiation using laser or LED, in doses of $6 \mathrm{~J} / \mathrm{cm}^{2}$ and $10 \mathrm{~J} / \mathrm{cm}^{2}$, increase the tissue resistance to rupture but decrease the strength capacity. The lack of deformation is probably due to an increased recruitment of fibroblast cells, which synthesize collagen, giving more resistance to the tissue but lower deformation capacity, also justifying the presence of increased tissue deformation in control and LED $10 \mathrm{~J} / \mathrm{cm}^{2}$ groups.

Tissue heating presented minor values which limited possible conclusions concerning this property, mainly due to accuracy limits of the instrument. Moreover, preliminary results advise that the increase in tissue temperature during LILT or LED irradiation is not sufficient to cause damage, as demonstrated by the microscopic analysis, even around metal suture.

\section{References}

Andrade MF, Rastelli ANS, Saad RS, Saad JRC. Avaliação de capacidade de polimerização de um dispositivo a base de LED à bateria. Journal of the American Dental Association. 2001; 4:372-76.

Baum CL, Arpey CJ. Normal cutaneous wound healing: clinical correlation with cellular and molecular events. Dermatologic Surgery. 2005; 31(6):674-86. PMid:15996419. http://dx.doi.org/10.1111/j.1524-4725.2005.31612

Brocki BC, Thorup CB, Andreasen JJ. Precautions related to midline sternotomy in cardiac surgery: a review of mechanical stress factors leading to sternal complications. European Journal of Cardiovascular Nursing. 2010; 9(2):77-84. PMid:20051323. http://dx.doi. org/10.1016/j.ejcnurse.2009.11.009

Brugnera JRA. Biomodulatory effect of lasertherapy-clinical indications. Brazilian Dental Journal. 2004; 15(Suppl):60.

Capon A, Mordon S. Can thermal lasers promote skin wound healing?. American Journal of Clinical Dermatology. 2003; 4(1):1-12. http://dx.doi. org/10.2165/00128071-200304010-00001

Casalechi HL, Nicolau RA, Casalechi VL, Silveira L, De Paula AMB, Pacheco MTT. The effects of low-level light emitting diode on the repair process of Achilles tendon therapy in rats. Lasers in Medicine Science. 2009. 24:659-65. PMid:18795398. http://dx.doi.org/10.1007/s10103-0080607-6

Circeli GZ, Pavarina AC, Ribeiro APD, Trindade FZ, Inada NM, Bagnato VS, Costa CAS. Efeito de diferentes fluências e intensidades de luz LED azul e vermelha em cultura de fibroblastos. Revista de Odontologia da UNESP. 2009; 3:84.

Corazza AV, Jorge J, Kurachi C, Bagnato VS. Photobiomodulation on the angiogenesis of skin wounds in rats using different light sources. Photomed Laser Surgery. 2007; 25(2):102-6. PMid:17508845. http://dx.doi. org/10.1089/pho.2006.2011

De Araujo CE, Ribeiro MS, Favaro R, Zezell DM, Zorn TM. Ultrastructural and autoradiographical analyses show a faster skin repair in He-Ne laser-treated wounds. Journal of Photochemistry Photobiology. 2007; 86(2):87-96. PMid:17029969. http://dx.doi.org/10.1016/j. jphotobiol.2006.08.006

Dall-Agnol MA, Nicolau RA, De Lima CJ, Muniz E. Comparative analysis of coherent light action (laser) versus non-coherent light (light-emitting diode) for tissue repair in diabetic rats. Lasers in Medical Science. 2009; 24(6):909-16. PMid:19238507. http://dx.doi.org/10.1007/s10103-0090648-5

Fushimi T, Inui S, Nakajima T, Ogasawara M, Hosokawa $\mathrm{K}$, Itami S. Green light emitting diodes accelerates wound healing: Characterization of the effect and its molecular basis in vitro and in vivo. Wound Repair \& Regeneration. 2012; 20(2): 226-35. PMid:22380691. http:// dx.doi.org/10.1111/j.1524-475X.2012.00771.x

Giuliani A, Fernandez M, Farinelli M, Baratto L, Capra R, Rovetta G, Monteforte P, Giardino L, Calzà L. Very low level laser therapy attenuates edema and pain in experimental models. International Journal of Tissue Reaction. 2004; 26(1-2):29-37. Pmid:15573690.

Guaratini T, Medeiros MHG, Colopicolo P. Antioxidantes na manutenção do equilíbrio redox cutâneo: uso e avaliação de sua eficácia. Química Nova. 2007; 30(1):206-13. http:// dx.doi.org/10.1590/S0100-40422007000100033

Hawkins D, Abrahamse H. Laboratory methods for evaluating the effect of low level therapy (LILT) in wound healing. African Journal of Biomedicine Review. 2005; 8:1-14.

Houreld N, Abrahamse H. In vitro exposure of wounded diabetic fibroblast cells to a helium-neon laser at 5 and 16 $\mathrm{J} / \mathrm{cm}^{2}$. Photomedical Laser Surgery. 2007; 25(2):78-84. PMid:17508841. http://dx.doi.org/10.1089/pho.2006.990

Ignatieva NY, Guller AE, Zakharkina OL, Sandnes B, Shekhter AB, Kamensky VA, Zvyagin AV. Laser-induced modification of the patellar ligament tissue: comparative study of structural and optical changes. Lasers in Medicine Sciences. 2011; 26(3):401-13. PMid:21190054 PMCid:3069329. http://dx.doi.org/10.1007/s10103-0100871-0

Kurachi C, Tuboy AM, Magalhães DV, Bagnato VS. Hardness evaluation of a dental composite polymerized with experimental LED-based device. Dental Materials. 2001; 4:309-15. http://dx.doi.org/10.1016/ S0109-5641(00)00088-9

Leal Junior EC, Lopes-Martins RA, Vanin AA, Baroni BM, Grosselli D, De Marchi T, Iversen VV, Bjordal JM. Effect of 830-nm low-level laser therapy on exercise-induced skeletal muscle fatigue in humans. Lasers in Medicine Sciences. 2009;24(3):425-31. PMid:18649044. http://dx.doi. org/10.1007/s10103-008-0592-9

Lorenzini L, Giuliani A, Giardino L, Calzà L. Laser acupuncture for acute inflammatory, visceral and neuropathic pain relief: An experimental study in the laboratory rat. Research in Veterinary Science. 2010; 88(1):159-65. PMid:19560793. http://dx.doi.org/10.1016/j.rvsc.2009.06.001 
Meyer PF, Araújo HG, Carvalho MGF, Tatum BIS. Avaliação dos efeitos do LED na cicatrização de feridas cutâneas em ratos Wistar. Fisioterapia Brasil. 2010; 11(6):428-32.

Minatel DG, Frade MA, França SC, Enwemeka CS. Phototherapy promotes healing of chronic diabetic leg ulcers that failed to respond to other therapies. Lasers Surgery in Medicine. 2009; 41(6):433-41. PMid: 19588536. http://dx.doi.org/10.1002/1sm.20789

Reis SR, Medrado AP, Marchionni AM, Figueira C, Fracassi LD, Knop LA. Effect of 670-nm laser therapy and dexamethasone on tissue repair: a histological and ultrastructural study. Photomedical Laser Surgery. 2008; 26(4):307-13. PMid:18665765. http:// dx.doi.org/10.1089/pho.2007.2151

Sousa AP, Santos JN, Dos Reis JA Jr, Ramos TA, De Souza J, Cangussú MC, Pinheiro AL. Effect of LED phototherapy of three distinct wavelengths on fibroblasts on wound healing: a histological study in a rodent model. Photomed
Laser Surgery. 2010; 28(4): 547-52. PMid:20001321. http:// dx.doi.org/10.1089/pho.2009.2605

Trelles AM, Allones EM. Red light-emitting diode (LED) therapy accelerates wound healing post-blepharoplasty and periocular laser ablative resurfacing. Journal of Cosmect and Laser Therapy. 2006; 8(1):39-42. PMid:16581685. http://dx.doi.org/10.1080/14764170600607731

Uribe RC, Vargas FM, Héctor S, Onate OG. Morphometric and ultrastructural studies of the effect of infrared laser on rabbit temporo-mandibular joint fibroblasts. Brazilian Archieves of Biology Technology. 2009; 52(3): 611-16. http://dx.doi.org/10.1590/S1516-89132009000300013

Whelan HT, Smits RL, Buchman EV, Whelan NT, Turner SG, Margolis DA. Effect of NASA emitting diode irradiation in wound healing. Journal of Clinical Laser in Medicine and Surgery. 2001; 19(6):305-14. PMid:11776448. http:// dx.doi.org/10.1089/104454701753342758

\footnotetext{
Authors

Rauirys de Alencar de Oliveira*, André Fernandes Matos, Nara Regina Batista Barros, Gilderlene Alves Fernandes Faculdade de Saúde, Ciências Humanas e Tecnológicas do Piauí, Centro de Saúde. Rua Vitorino Orthigues Fernandes, 6123, Uruguay, CEP 64057-100, Teresina, PI, Brasil.
}

\section{Andréa Conceição Gomes Lima}

Universidade Estadual do Piauí. Rua Olavo Bilac, 2335, Centro/Sul, CEP 64001280, Teresina, PI, Brasil.

\section{Renata Amadei Nicolau}

Universidade do Vale do Paraíba, Faculdade de Ciências da Saúde. Av. Shishima Hifumi, 2911, Urbanova, CEP 12244-000, São José dos Campos, SP, Brasil. 